\title{
Geoelectrical and Geochemical Characterization of Groundwater in a Shallow Coastal Aquifer
}

\author{
María Ladrón de Guevara-Torres ${ }^{1}$, Héctor J. Peinado-Guevara ${ }^{2 *}$, \\ Omar Delgado-Rodríguez ${ }^{3}$, Vladimir Shevnin ${ }^{4}$, Jaime Herrera-Barrientos ${ }^{5}$, \\ Salvador Isidro Belmonte-Jiménez ${ }^{1}$, Víctor M. Peinado-Guevara ${ }^{2}$ \\ ${ }^{1}$ Instituto Politécnico Nacional, Unidad CIIDIR-Oaxaca. \\ Hornos No. 1003, Noche Buena, Santa Cruz Xoxocotlán, Oaxaca, México \\ ${ }^{2}$ Escuela de Ciencias Económicas y Administrativas, Universidad Autónoma de Sinaloa, \\ Blvd. Juan de Dios Bátiz s/n, San Joachín, Guasave, Sinaloa, México \\ ${ }^{3}$ División de Geociencias Aplicadas, Instituto Potosino de Investigación Científica y Tecnológica. \\ Camino a la Presa San José 2055. Lomas 4 Sección, San Luis Potosí, S.L.P., México \\ ${ }^{4}$ Moscow State University, Moscow, Russia \\ ${ }^{5}$ Centro de Investigación Científica y de Educación Superior de Ensenada, Baja California, \\ Carretera Ensenada-Tijuana No. 3918, Zona Playitas, Ensenada, B.C. México
}

Received: 15 November 2016

Accepted: 11 January 2017

\begin{abstract}
Playa Las Glorias is the main tourist destination for the inhabitants of the municipality of Guasave, Sinaloa, México, and it overlies a shallow coastal aquifer. In recent years, the momentum of the tourism industry in the region has brought a growing demand in the consumption of drinking water. Because of this, it is relevant to the precise knowledge of the interface of slightly brackish saltwater for an efficient planning of new wells by the municipal authorities. For efficient groundwater exploitation, it was taken into consideration the productivity of the aquifer and the environmental impact that would cause improper management of water resources. The electromagnetic profiling (EMP) method was applied in Playa Las Glorias, Sinaloa, Mexico. A total of 150 measurements of EMP distributed in 11 profiles were performed, of which 10 were perpendicular to the coast and one parallel to it, using an EM34 meter in horizontal polarization and separation between coils of $10 \mathrm{~m}$ and $20 \mathrm{~m}$. The apparent conductivity maps show an anomaly of low conductivity, indicating the presence of fresh or slightly saline water. In this anomalous zone we performed an electric resistivity tomography (ERT) profile to determine the behavior of groundwater salinity finding a shallow layer of freshwater, and as it deepens the salinity increases due to the influence of the sea. In addition, electrical resistivity $\left(\mathrm{R}_{\mathrm{w}}\right)$ values were measured in groundwater samples that, along with the resistivity values $\left(\mathrm{R}_{\mathrm{o}}\right)$ for sandy formation obtained from ERT data, allowed us to determine a lineal relationship between both resistivities. A hydro geochemical study was conducted in the site through Piper diagrams and Chadha, indicating a predominance in the region of chlorinated water due to the influence
\end{abstract}

*e-mail: hpeinado75@hotmail.com 
of the nearby sea. Finally, we determined the correlations between the water electrical conductivity values with the $\mathrm{Cl}^{-}$anion and the $\mathrm{Na}^{+}$and $\mathrm{Mg}^{2+}$ cations for the site, besides finding relationships between $\mathrm{Na}^{+}-\mathrm{Cl}^{-}$, $\mathrm{Na}^{+}-\mathrm{Mg}^{2+}$, and $\mathrm{Cl}^{-}-\mathrm{Mg}^{2+}$ with a superior adjustment to 0.98 .

Keywords: electromagnetic profiling, electrical resistivity tomography, anions and cations, hydrogeochemistry and salinity

\section{Introduction}

Groundwater plays an important role in sustainable ecosystems, enabling humans to adapt to climate change [1]. Marine intrusion is a global problem, recrudesced by the growing demand for fresh water in coastal areas and the proneness to the influences of sea level rise and climate change [2-5]. The vulnerability of coastal aquifers is an intrinsic feature of them that relates to the geological structure, topography, and dynamics of groundwater flow [6]; and as fresh and salt water are miscible, there is a transition zone where these waters are gradually mixed by diffusion processes. The degree of groundwater vulnerability is affected by seasonal variations in groundwater recharge during the year [7].

The transition zone is a result of mechanical dispersion processes and molecular diffusion, and the theoretical Ghyben Herzberg interface is located within it [8]. The mixing zone may be displaced because of the reduced flow of fresh water to the sea, of increased permeability and heterogeneity, and of the density difference and the fluctuations of the tides. In a coastal aquifer without exploitation, there is a fresh-salt water balance that depends on the volume of fresh water poured into the sea [9]. For efficient groundwater exploitation, we took into consideration the productivity of the aquifer and the environmental impact that would cause improper management of water resources. For the particular case of coastal aquifers, excessive extraction of water resulted in the advance of saltwater intrusion on wells and farmland with devastating effects on agriculture, industry, and quality of life for the local population.

The quality of the groundwater depends on consistence of bedrock, topography, geology, soils, climate, atmospheric precipitation, the composition of recharged water, and anthropogenic pollution sources, among other factors $[10,11]$, and under the surface it shows the mixed effects of many processes in the groundwater flow path [12]. Hydrochemical diagrams allow for the graphic representation of the major chemical characteristics of water, thereby facilitating its classification. Piper or triangular diagrams are ideal for representing three components (anions and/or cations) simultaneously. This diagram has the advantage of representing various types of analyses on the same graph without confusion [1315]. Piper diagrams were made in such a way that the milliequivalent percentages of the major cations and anions are plotted in a separate triangle $[16,17]$. Chemically similar waters are found clustered, and can be classified by their location in the diagram. The Chadha diagram is a proposal for geochemical classification of natural waters and of the interpretation of chemical data, complying with the basic requirement for proper classification of natural waters, and can also be used effectively for the study of hydrochemical processes [18].

The implementation of geophysical methods based on non-destructive techniques of very-low frequency electromagnetic induction and two-dimensional electrical resistivity tomography are useful for recognizing the subsoil $[19,20]$. The application of resistivity methods is very wide, because we can study and monitor the migration of $\mathrm{CO}_{2}$ in the aquifer [21, 23], groundwater drawdown and rebound [24], monitoring freshwater salinization [25], archeology [26], bedrock detection [27], and compaction control of clayey soils [28]. The joint application of electromagnetic profiling and electrical resistivity tomography methods gives a fast and efficient procedure for studying shallow aquifers.

Archie [29] proposed a relationship between the $R_{0}$ and $R_{w}$. Although Archie worked with clean sand and brines, several authors have worked in various geological environments and have uncovered relationships through experimentation with materials that were certainly not clean sands and that contained different concentrations of clay [30-35].

This paper shows the results of the implementation of the electromagnetic profiling and electrical resistivity

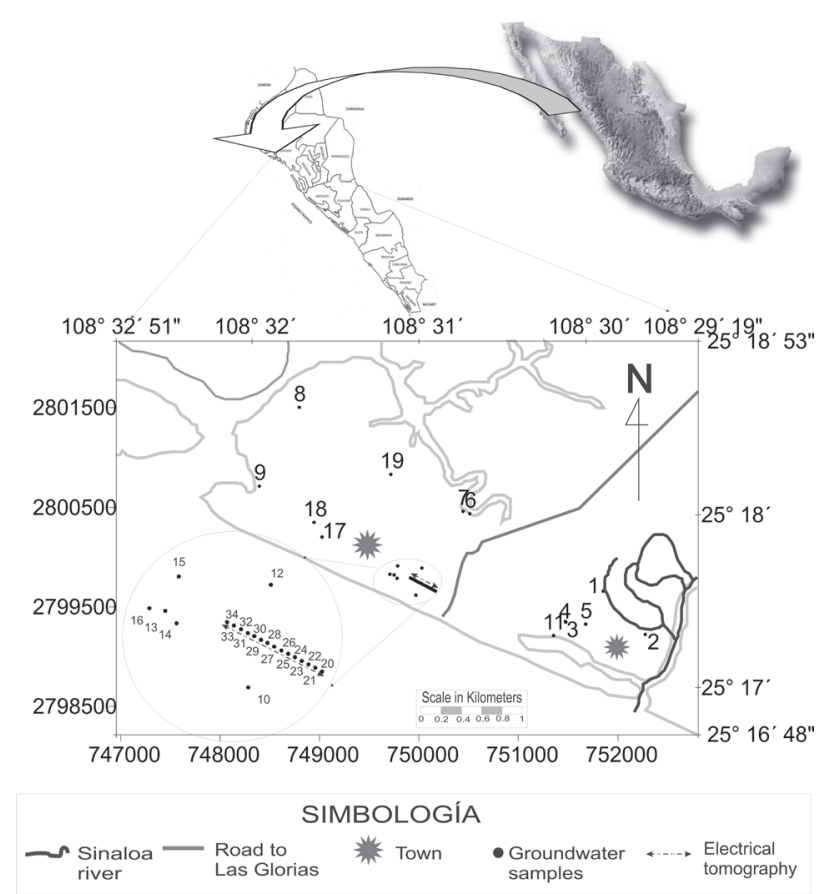

Fig. 1. Location of the study area. 
tomography methods to delineate aquifers of fresh and brackish water, as well as the transition zone freshwater-saltwater. Furthermore, geochemical studies of groundwater samples allowed for classifying them by determining their predominant anions and cations, and its salinity according to their values of total dissolved solids.

\section{Materials and Methods}

\section{Study Area}

Playa Las Glorias, with its fine sand and a $4.7 \mathrm{~km}$ shoreline, is a resort center and the main tourist destination in the municipality of Guasave. The study area is located between the coordinates $25^{\circ} 16^{\prime} 48^{\prime \prime}$ and $25^{\circ} 18^{\prime} 53^{\prime \prime}$ north latitude and $108^{\circ} 29^{\prime} 19^{\prime \prime}$ and $108^{\circ} 32^{\prime} 51^{\prime \prime}$ west longitude (Fig. 1). Playa Las Glorias has a warm tropical climate with an annual average temperature of $25.3^{\circ}$ [36]. The average annual rainfall in Guasave station is $414.7 \mathrm{~mm}$ [37]. The soils of the site are of Aeolian origin of the Cenozoic era, quaternary period.

The drinking water in the village Las Glorias is supplied from distant groundwater wells $(\sim 20 \mathrm{~km})$, so the few existing wells have a regime of low operation and are of a seasonal nature related to the irrigation of plants and other domestic uses. In recent years, the momentum of the tourism industry in the region has brought a growing demand in the consumption of drinking water for Playa Las Glorias. Because of this, it is relevant precise knowledge of the interface of slightly brackish saltwater for the efficient planning of new wells by the municipal authorities.

\section{The Electromagnetic Profiling (EMP) Method}

The application of the EMP method involves measuring the response of the subsurface to an electromagnetic field. An electromagnetic field is generated by a transmitter coil, inducing eddy currents in the ground. These induced currents generate a secondary magnetic field, which is a function of the inter-coil spacing, operating frequency, and ground conductivity. Both the primary and secondary magnetic fields are measured in a receiver coil ground conductivity, resulting from geological characteristics and conductive materials (metallic objects) and contaminants, and can be calculated at a specific study depth from the ratio of the secondary and primary magnetic fields [38] using the following equation:

$$
E C_{a}=\frac{4}{\omega \mu_{0} r^{2}}\left(\frac{H_{s}}{H_{p}}\right)
$$

...where $\mathrm{EC}_{\mathrm{a}}$ is the apparent electrical conductivity of the soil $(\mathrm{mSiemens} / \mathrm{m}) ; H_{s}$ is the secondary magnetic field measured in the receiver coil; $H_{p}$ is the primary magnetic field measured in the receiver coil; $\omega$ is $2 \pi \mathrm{f}$, where $\mathrm{f}(\mathrm{Hz})$ is the frequency of the EM signal; $\mu_{0}$ is vacuum magnetic permeability; and $r$ is the distance between the transmitter and receiver coils.

In this work, using the EM34 meter [39], $150 \mathrm{EC}_{\mathrm{a}}$ measurements were obtained in the study site. Soil conductivity measurements were performed to inter-coil spacing and operating frequency of $10 \mathrm{~m}(6.4 \mathrm{KHz})$ and $20 \mathrm{~m}(1.6 \mathrm{KHz})$, ensuring, in horizontal dipole mode, a maximum study depth of $7.5 \mathrm{~m}$ y $15 \mathrm{~m}$, respectively. In order to define the location of low-conductivity anomalies related to the presence of saturated sands of fresh or slightly brackish water, measurements were settled in 11 profiles: 10 perpendicular to the coastline and one parallel.

\section{The Electrical Resistivity Tomography (ERT) Method}

The vertical electrical sounding method, known worldwide since the beginning of the 1920s, was created by the Schlumberger brothers in France. They made a design using four electrodes (two for electric current injection and the two for measuring potential difference). By increasing the distance between current electrodes, the study depth will increase as well [38]. Technically the method is very simple and is currently used primarily for near surface studies. In 1990 a new stage in the development of this method began with the emergence of technology called resistivity imaging or electric resistivity tomography (ERT). The application of the ERT method is based on apparent resistivity determination with the help of a linear array (e.g., Dipole-Dipole, WennerSchlumberger) of many electrodes connected to resistivity equipment. ERT is applied to obtain a geoelectrical image of the sub-surface using electrical measurements made along the profile at the surface. Such profile measurements allow for two-dimensional interpretation using software such as Res2DInv [40-41]. As a result of interpretation, true layers' resistivity and their thickness are estimated. Resistivity data are then processed to obtain a resistivity cross-section. This two-dimensional interpretation has several good features that make the interpretation results suitable for good visualization [42].

The ERT method was included in this study for application in areas of interest defined by the EMP method, such as on the anomalous EMP zones ERT applied to obtain sections of interpreted resistivity that define not only the stratigraphy of the site but the position of the aquifer and the transition zones of sweet-brackish-salty water. An ERT profile of $280 \mathrm{~m}$ length was conducted using Wenner-Schlumberger in accordance with sounding point spacing of $4 \mathrm{~m}$. In total, 68 points of ERT were taken with a separation between electrodes of $2 \mathrm{~m}$ and a maximum spacing $\mathrm{AB} / 2=20 \mathrm{~m}$. Each point was geopositioned with a portable GPS eTrex H-brand Garmin.

\section{Chemical Analysis of Water Samples}

Thirty-four samples were collected in the study area, six of which correspond to surface waters (one of the sea, one 
of the estuary, two from evaporated bodies, and two from the Sinaloa River), and the rest are groundwater collected in well. Electrical conductivity (EC) was determined in the 34 samples, $\mathrm{pH}$, anions, and cations $\left(\mathrm{Ca}^{2+}, \mathrm{Mg}^{2+}, \mathrm{Na}^{+}\right.$, $\mathrm{CO}_{3}, \mathrm{HCO}_{3}^{-}, \mathrm{SO}_{4}^{-}$, and $\mathrm{Cl}^{-}$), while total dissolved solids were determined from the latter. Electrical conductivity and $\mathrm{pH}$ were determined in situ using a previously calibrated Hanna HI98130 portable kit.

In the groundwater laboratory of the National Water Commission of Irrigation District 063, the contents of chlorides, carbonates, bicarbonates, magnesium, calcium, sodium, and sulfates were determined according to the manual proposed by [43].

For determining the behavior of salinity in the area, waters were classified according to total dissolved solids (TDS, $\mathrm{mg} / \mathrm{l}$ ) considering the following ranges: TDS $<1,000 \mathrm{mg} / \mathrm{l}$ is fresh water; $1,000 \leq \mathrm{TDS} \leq 3,000 \mathrm{mg} / \mathrm{l}$ is slightly saline; $3,000<\mathrm{TDS} \leq 10,000 \mathrm{mg} / 1$ is moderately saline; $10,000<\mathrm{TDS} \leq 35,000$ very saline; and TDS $>$ $35,000 \mathrm{mg} / \mathrm{l}$ is considered brine [44].

Hydrochemical classification was performed by Piper diagrams and Chadha, to identify the types of water present in the area. To interpret the Piper diagram in more detail, it should be considered necessary for its construction that the ions are reduced to a percentage of milliequivalents per liter $(\mathrm{mg} / \mathrm{l})$. To each vertex of a triangle corresponds $100 \%$ of specific ions. The Chadha diagram was created by comparing in percentages of milliequivalents the differences between weak and strong anions against the differences between alkaline earth elements and alkaline elements. This assumes that the concentrations of $\mathrm{Cl}^{-}$, $\mathrm{SO}_{4}^{2-}, \mathrm{HCO}_{3}^{--}, \mathrm{CO}_{3}^{2-}, \mathrm{Na}^{+}, \mathrm{Ca}^{2+}$, and $\mathrm{Mg}^{2+}$ ions are highest in the water. For constructing the Gibbs diagram, total dissolved solids are graphed (TDS) in function of the cationic ratio $\left(\mathrm{Na}^{+} /\left(\mathrm{Na}^{+}+\mathrm{Ca}^{2+}\right)\right.$ and anionic $\mathrm{Cl}^{-} /$ $\left(\mathrm{Cl}^{-}+\mathrm{HCO}_{3}^{-}\right)$of the water. In addition, a statistical analysis was carried out with nine hydrochemical variables (EC, $\mathrm{Ca}^{2+}, \mathrm{Mg}^{2+}, \mathrm{Na}^{+}, \mathrm{CO}_{3}^{-}, \mathrm{HCO}_{3}^{-}, \mathrm{SO}_{4}^{-}, \mathrm{Cl}^{-}$, and $\left.\mathrm{pH}\right)$.

The resistivity of the saturated thickness $\left(\mathrm{R}_{\mathrm{o}}\right)$ obtained in the field is empirically correlated with the subsurface water resistivity $\left(\mathrm{R}_{\mathrm{w}}\right)$ obtained by direct measurement using a lineal function. With this relationship, it is assumed with the resistivity values of the soil the resistivity values interpreted by ERT and with the relationships found between electrical conductivity with some ions and salinity, then it is possible to estimate maps of the behavior of the chloride anion and sodium and magnesium cations.

\section{Results and Discussion}

\section{Maps of Apparent Electrical Conductivity}

Fig. 2 shows the results of EMP measurements where in the central part of the study site a low conductivity zone is observed, so much for the spacing between coils of $10 \mathrm{~m}$ (Fig. 2a) as of $20 \mathrm{~m}$ (Fig. 2b). Bearing in mind that the average depth of the water table of the site is $1 \mathrm{~m}$, low conductivity should reflect the effect of less concentration
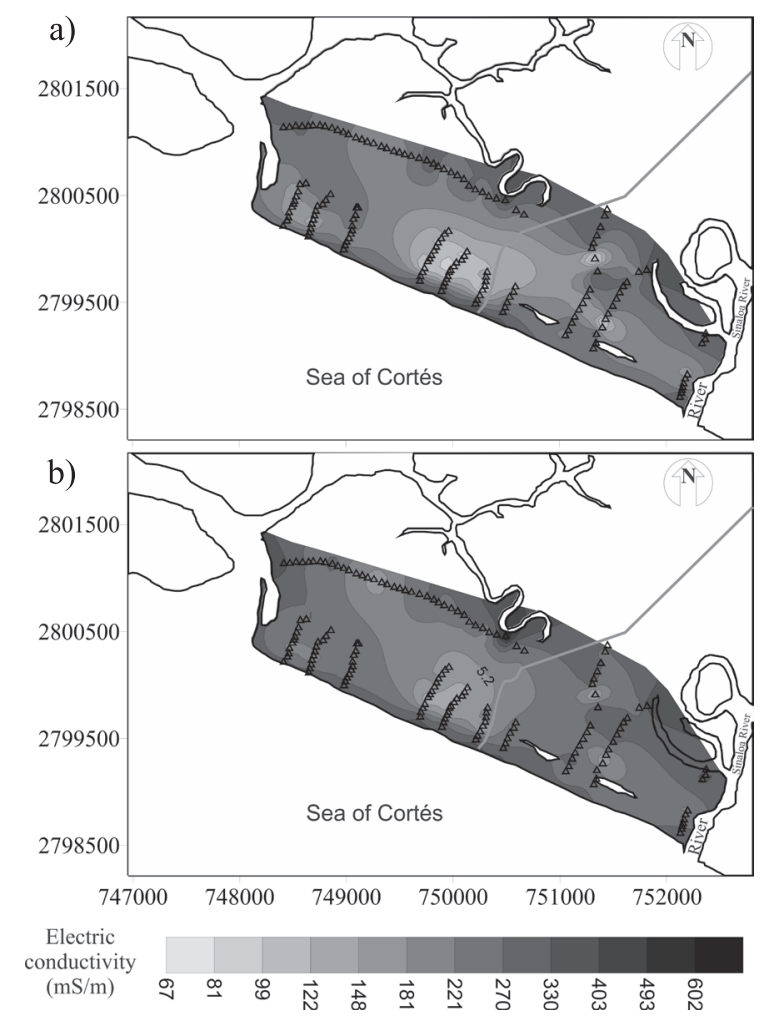

Fig. 2. Map of the behavior of the apparent EC values obtained from the EMP survey: spacing between coils: a) $10 \mathrm{~m}$ and b) $20 \mathrm{~m}$.

of salts in the water that saturates the sandy subsoil. The area of low conductivity is similar to a channel that apparently comes from infiltrations of the river Sinaloa, which is positioned parallel to the coast as a barrier of fresh or brackish water, which can be corroborated by the behavior of the electrical conductivity of the water samples collected from wells. Due to its proximity to the coastline, this body of sand saturated with fresh or brackish water is

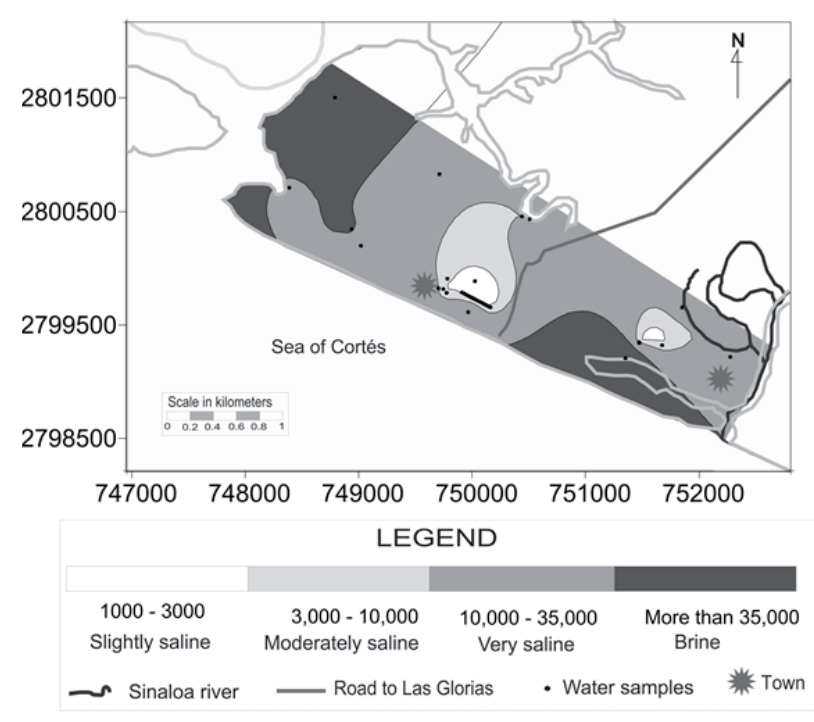

Fig. 3. Classification of water based on total dissolved solids. 


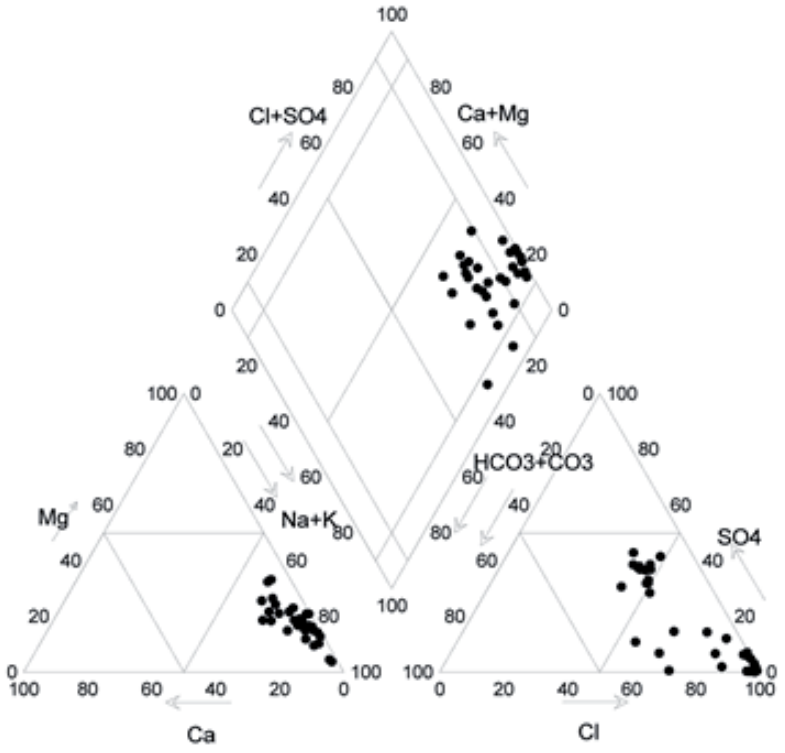

Fig. 4. Behavior of water according to Piper diagram.

vulnerable to saltwater contamination because it is in the urban area. Natural events in the past have led seawater to penetrate this area. For the separation of the coils of $20 \mathrm{~m}$ (depth study equal to $15 \mathrm{~m}$ ), the conductivities increase due to an increase in pore water salinity with depth, which makes sense because of the influence of the sea. Herber [45] has established the ECa measurements as a tool convenience and reliability of variation and spatial heterogeneity of soil properties in a specific site.

\section{Classification of the Shallow Coastal Aquifer Based} on Total Dissolved Solids (TDS)

From the 34 samples collected in the study area, the behavior of salinity was determined by considering the

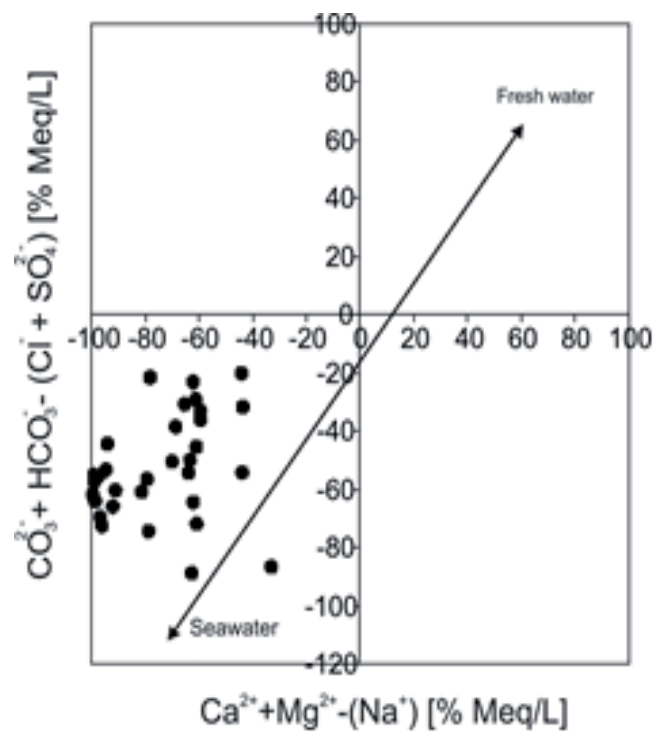

Fig. 5. Graphical representation of the Chadha diagram.
TDS content. Fig. 3 shows the predominance of saline water $(10,000<\operatorname{TDS}<35,000 \mathrm{ppm})$. In the central and eastern parts of the site, a small portion of slightly saline water (TDS $<3,000 \mathrm{ppm}$ ) is observed, which is remarkable as it provides a source of water for a great variety of plant development and domestic use. There are brines in the area in the adjacent portions to the Sea of Cortés (>35,000 mg/l, see footnote in Fig. 3).

\section{Hydrochemistry}

We used the information of anions and cations of the analysis of the 34 available samples to obtain Piper and Chadha diagrams. In the Piper diagram (Fig. 4) we can see that waters are classified as chlorinated and/or sodium sulfated, with sodium and chlorine being the main ionic elements present in the analyzed samples. In the Chadha diagram water samples scattered in the lower left quadrant are observed, predominantly sodium and chloride ions, tending to brackish water (see Fig. 5).

The predominance of chloride and sodium ions are evident by the proximity to the coast and are related to those obtained in other coastal aquifers by [46-47] to present similar results in the Piper diagram [13].

To explain the geochemical processes controlling the chemical composition of these waters we used the diagram proposed by Gibbs [48]. In this diagram (Fig. 6) the TDS are graphed according to the cationic ratio $\mathrm{Na}^{+} /\left(\mathrm{Na}^{+}+\mathrm{Ca}^{2+}\right)$ and anionic $\mathrm{Cl}^{-} /\left(\mathrm{Cl}^{-}+\mathrm{CO}_{3}{ }^{2-}+\mathrm{HCO}_{3}{ }^{-}\right)$ of the waters.

Fig. 6 shows that the water samples are located in the upper third right of the graph, being the dominant process of the evaporation as the cationic or anionic ratio close to 1 and TDS are high.

\section{Statistical Analysis}

Of the 34 water samples analyzed, 28 are from shallow wells. The $\mathrm{pH}$ range was 7 to 9.7 , with an average of 7.8,
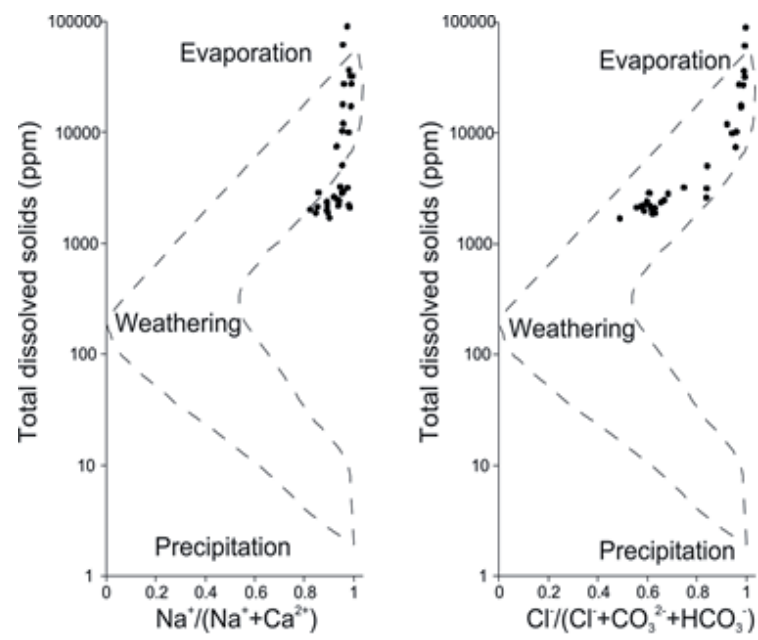

Fig. 6. Gibbs diagrams: anionic and cationic ratio vs. total dissolved solids. 
Table 1. Correlation matrix of nine variables calculated from chemical data of groundwater samples collected from wells and superficial water samples, analyzed in 2008.

\begin{tabular}{|c|c|c|c|c|c|c|c|c|c|}
\hline & $\mathrm{EC}$ & $\mathrm{Ca}^{2+}$ & $\mathrm{Mg}^{2+}$ & $\mathrm{Na}^{+}$ & $\mathrm{CO}_{3}{ }^{2-}$ & $\mathrm{HCO}_{3}{ }^{-}$ & $\mathrm{SO}_{4}^{2-}$ & $\mathrm{Cl}^{-}$ & $\mathrm{pH}$ \\
\hline $\mathrm{EC}$ & 1.000 & & & & & & & & \\
\hline $\mathrm{Ca}^{2+}$ & 0.839 & 1.000 & & & & & & & \\
\hline $\mathrm{Mg}^{2+}$ & $\mathbf{0 . 9 8 7}$ & 0.874 & 1.000 & & & & & & \\
\hline $\mathrm{Na}^{+}$ & $\mathbf{0 . 9 9 5}$ & 0.864 & $\mathbf{0 . 9 8 7}$ & 1.000 & & & & & \\
\hline $\mathrm{CO}_{3}{ }^{2-}$ & -0.176 & -0.226 & -0.216 & -0.168 & 1.000 & & & & \\
\hline $\mathrm{HCO}_{3}{ }^{2}$ & -0.454 & -0.319 & -0.488 & -0.451 & 0.113 & 1.000 & & & \\
\hline $\mathrm{SO}_{4}^{2-}$ & 0.669 & 0.777 & 0.698 & 0.691 & -0.154 & -0.200 & 1.000 & & \\
\hline $\mathrm{Cl}^{-}$ & $\mathbf{0 . 9 9 5}$ & 0.866 & $\mathbf{0 . 9 9 1}$ & $\mathbf{0 . 9 9 9}$ & -0.181 & -0.466 & 0.674 & 1.000 & \\
\hline $\mathrm{pH}$ & -0.272 & -0.336 & -0.324 & -0.254 & 0.596 & -0.036 & -0.104 & -0.274 & 1.000 \\
\hline
\end{tabular}
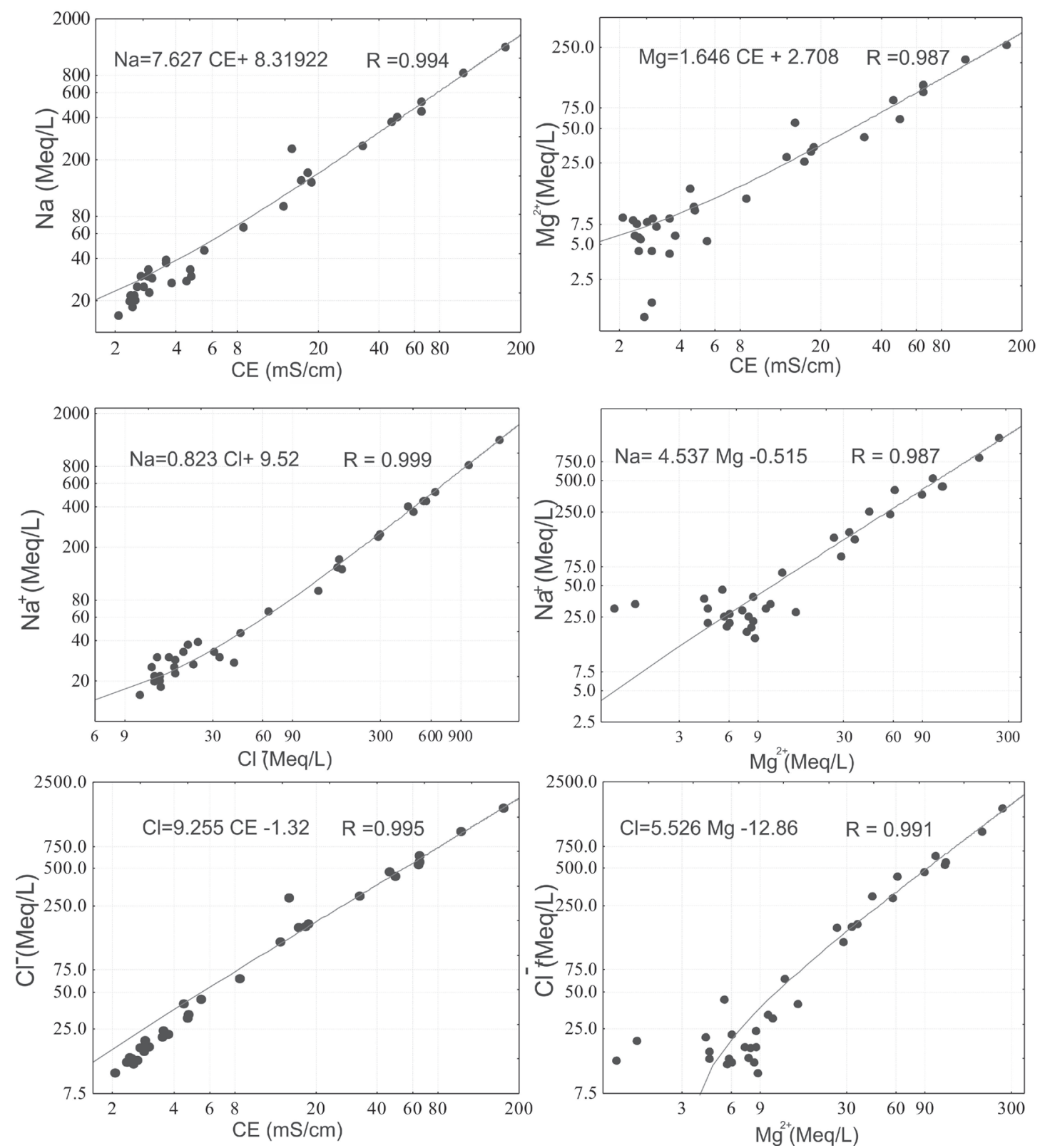

Fig. 7. Relationships between $\mathrm{Na}^{+}-\mathrm{EC}, \mathrm{Mg}^{2+}-\mathrm{EC}, \mathrm{Na}^{+}-\mathrm{Cl}^{-}, \mathrm{Na}^{+}-\mathrm{Mg}^{2+}, \mathrm{Cl}-\mathrm{EC}$, and $\mathrm{Cl}^{-}-\mathrm{Mg}^{2+}$ in Playa Las Glorias. 
Table 2. Analysis of textures of the saturated zone where the ERT method was applied.

\begin{tabular}{|c|c|c|c|c|}
\hline $\begin{array}{c}\text { Sampling } \\
\text { point }\end{array}$ & $\%$ Sand & $\%$ Silt & $\%$ Clay & Classification \\
\hline 0 & 94 & 3 & 2 & Sandy \\
\hline 20 & 92 & 5 & 2 & Sandy \\
\hline 40 & 94 & 3 & 2 & Sandy \\
\hline 60 & 94 & 2 & 4 & Sandy \\
\hline 40 & 94 & 3 & 2 & Sandy \\
\hline 100 & 94 & 3 & 2 & Sandy \\
\hline 120 & 92 & 5 & 3 & Sandy \\
\hline 140 & 93 & 3 & 4 & Sandy \\
\hline 160 & 91 & 5 & 4 & Sandy \\
\hline 180 & 91 & 5 & 4 & Sandy \\
\hline 200 & 93 & 3 & 4 & Sandy \\
\hline 220 & 93 & 3 & 4 & Sandy \\
\hline 240 & 93 & 3 & 4 & Sandy \\
\hline 260 & 92 & 3 & 5 & Sandy \\
\hline 280 & 92 & 3 & 5 & Sandy \\
\hline
\end{tabular}

which indicates a slight tendency to a basic composition. The electrical conductivity varied between 2.07 and $167.6 \mathrm{mS} / \mathrm{cm}$, with an average of $21.93 \mathrm{mS} / \mathrm{cm}$. Table 1 shows that high salinity is determined by the predominance of the major ions $\mathrm{Cl}^{-}$and $\mathrm{Na}^{+}$, which are correlated to electrical conductivity $\left(\mathrm{R}=0.995\right.$ for $\mathrm{Cl}^{-}$and $\mathrm{Na}^{+}$, respectively), besides finding relationships between $\mathrm{Na}^{+}-\mathrm{Cl}^{-}, \mathrm{Na}^{+}-\mathrm{Mg}^{2+}, \mathrm{Mg}^{2+}-\mathrm{Cl}^{-}, \mathrm{Na}^{+}-\mathrm{EC}, \mathrm{Mg}^{2+}-\mathrm{EC}$, and $\mathrm{Cl}^{-}-\mathrm{EC}$ with $\mathrm{R}>0.98$ in all cases. The effects of these ions on plant growth are generally evaluated by comparing the reaction of plants growing in isosmotic solutions of different salts [43]. Fig. 7 shows that the model fits better as it increases the concentration of the elements, missing the adjustment for EC values smaller than $3 \mathrm{mS} / \mathrm{cm}$ and values of anions and cations smaller than $3 \mathrm{meq} / \mathrm{l}$.

The electrical conductivity of water depends on the ions present, thus it is expected that some ions predominate over the others, and can be estimated in function on the $\mathrm{EC}$, such as has been established by several authors in different geological environments $[49,50]$.

\section{Determining Groundwater Salinity of the Shallow} Coastal Aquifer

\section{Analysis of Groundwater and Soil Samples}

The results of the measurements in situ and of the laboratory tests at 15 groundwater samples (samples 20-34), presented maximum EC of $3.5 \mathrm{mS} / \mathrm{cm}$, minimum $\mathrm{EC}$ of $2.1 \mathrm{mS} / \mathrm{cm}$, and a mean value of $2.7 \mathrm{mS} / \mathrm{cm}$ corresponding to salinities of $2.1,1.3$, and $1.6 \mathrm{~g} / \mathrm{l}$,

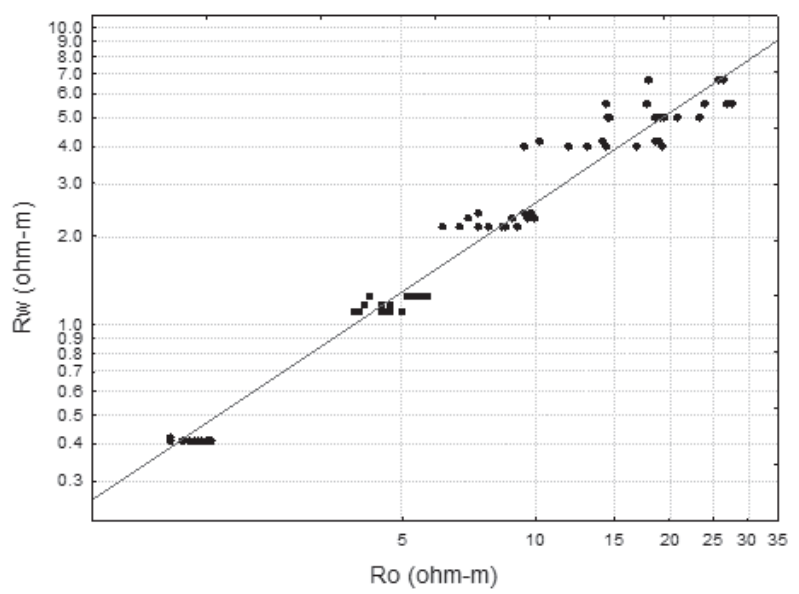

Fig. 8. Lineal correlation between $\mathrm{R}_{\mathrm{o}}$ and $\mathrm{R}_{\mathrm{w}}$.

respectively, indicating the presence of slightly saline water. A similar number of soil samples from the aquifer were analyzed to determine its texture under the Bouyoucos technique. The results indicate a variable content of clay between 2 and 5\% (see Table 2), so that in all cases it is a sandy soil with little variation in clay content where variations in soil resistivity will be controlled by variations of resistivity (or salt) of the water pore.

In the laboratory we determined the electrical resistivity to the 15 samples of sandy soil for $100 \%$ saturation with pore water of different salinities known in the range of $0.1 \mathrm{~g} / 1$ to $35 \mathrm{~g} / \mathrm{l}$ (from 4 to 5 different salinities per sample), obtaining a total of 70 pairs of values of $R_{0}$ and $R_{w}$, which were correlated by lineal function $\mathrm{R}_{\mathrm{w}}=0.259 \mathrm{R}_{\mathrm{o}}$, with an adjustment $\mathrm{R}=0.95$ (see Fig. 8).

The factor of apparent formation $\left(\mathrm{F}_{\mathrm{a}}\right)$ is 3.86 , which is similar to that found by [34], who won in their analysis, a $F_{a}=2.24$, for its part [33] of the presented analysis was identified a $\mathrm{F}_{\mathrm{a}}$ approximately 9.99 .

\section{Application of ERT method and Correlation between $\mathrm{R}_{\mathrm{w}}$ and $\mathrm{R}_{\mathrm{o}}$}

In the central portion of the study area an ERT profile was performed using a Wenner-Schlumberger array. Fifteen perforations were performed on the ERT profile with a depth of 1 to $1.7 \mathrm{~m}$ and spacing between them of $20 \mathrm{~m}$ to correlate the results of ERT with the information obtained on groundwater and subsurface. Fig. 9 shows the distribution of ERT points together with the perforations

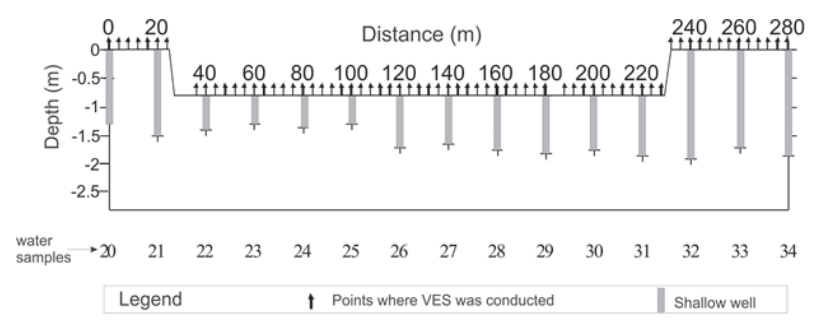

Fig. 9. Distribution of shallow wells and ERT points. 


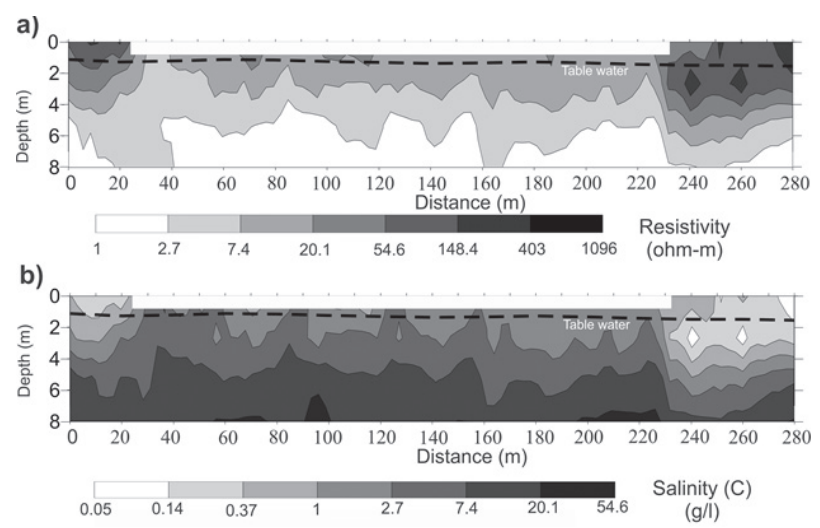

Fig. 10. Section of resistivity and salinity in Playa Las Glorias: a) interpreted resistivity applying the ERT method and b) behavior of pore water salinity.

with their depths. The water samples obtained in the saturated zone are listed in the lower part.

Using the lineal adjustment, values of electrical resistivity of the sandy subsoil $\left(\mathrm{R}_{\mathrm{o}}\right)$ were reconverted in water resistivity values $\left(R_{w}\right) \cdot R_{w}$ values were corrected to a temperature of $20^{\circ} \mathrm{C}$ in order to determine its salinity by establishing the ratio:

$$
\mathrm{C}=6 / \mathrm{R}_{\mathrm{w}}
$$

...where $\mathrm{C}$ is the content of salt $(\mathrm{NaCl}$ equivalent) in $\mathrm{g} / \mathrm{l}$ and $\mathrm{R}_{\mathrm{w}}$ is water resistivity for a reference temperature of $20^{\circ} \mathrm{C}$.

As a result of this procedure, the interpreted section of electrical resistivity (Fig. 10) was re-calculated to a section of the pore-water salinity (Fig. $10 \mathrm{~b}$ ), where it can be observed that the slightly salinized water is found from $1 \mathrm{~m}$ depth (phreatic level) to a depth of 3 to $4 \mathrm{~m}$, from which salinity is increased, being the most brackish water, corresponding to the defined low salinity defined by the EMP results (Figs 2-3).

\section{Conclusions}

The classification based on total dissolved solids shows the current situation found in Playa Las Glorias, Sinaloa, Mexico, presenting the points where it is possible to succeed in finding better quality water. The waters present in the study area are mainly dominated by sodium and chloride ions, which can be verified by Piper diagrams and Chadha, which gave similar results. With the proposed Gibbs diagram it was found that the geochemical processes controlling the chemical composition of water are by evaporation. Empirical relationships were found between EC with $\mathrm{Cl}^{-}, \mathrm{Na}^{+}$and $\mathrm{Mg}^{2+}+$, and also relationships between $\mathrm{Na}^{+}-\mathrm{Cl}^{-}, \mathrm{Na}^{+}-\mathrm{Mg}^{2+}$, and $\mathrm{Cl}^{-}-\mathrm{Mg}^{2+}$ with a good adjustment $(\mathrm{R}>0.98)$.

The EMP results show a low conductivity zone similar to a channel that apparently comes from infiltrations of the river Sinaloa, which is positioned parallel to the coast as a barrier of fresh or brackish water, which can be corroborated by the behavior of the EC values of the groundwater samples collected from wells. Due to its proximity to the coastline, this body of sand saturated with fresh or brackish water is vulnerable to saltwater contamination.

Taking into account the existing relationship between resistivity and salinity, it was possible to characterize the study site based on salt content. The ERT method is useful for detecting the interface of slightly brackish-salty water, which is relevant because it allows us to identify the spatial position of saline intrusion and thus the availability of better quality water, which in this case is above the saline intrusion with an average thickness of $2.5 \mathrm{~m}$, being highly vulnerable to saline intrusion and in the case of an increase of drilling in the area, the said thickness of the less salinized aquifer may disappear.

\section{Acknowledgements}

The authors thank the Mexican Petroleum Institute and the National Water Commission for its support with the geochemical analysis of soil and groundwater samples. Our gratitude to the General Direction of Research and Post graduate of the Autonomous University of Sinaloa for supporting the Project and generate the suitable conditions to fulfill the present work.

\section{References}

1. TAYLOR R.G., SCANLON B., DÖLL P., RODELL M., VAN BEEK R., WADA Y., KONIKOW L. Ground water and climate change. Nature Climate Change. 3 (4), 322, 2013.

2. WERNER A.D., BAKKER M., POST V.E., VANDENBOHEDE A., LU C., ATAIE-ASHTIANI B., BARRY D.A. Seawater intrusion processes, investigation and management: recent advances and future challenges. Advances in Water Resources. 51, 3, 2013.

3. FERGUSON G., GLEESON T. Vulnerability of coastal aquifers to groundwater use and climate change. Nature Climate Change. 2 (5), 342, 2012

4. ANDERSON F., AL-THANI N. Effect of Sea Level Rise and Groundwater Withdrawal on Seawater Intrusion in the Gulf Coast Aquifer: Implications for Agriculture. Journal of Geoscience and Environment Protection. 4 (04), 116, 2016.

5. LU C., XIN P., LI L., LUO J. Seawater intrusion in response to sea-level rise in a coastal aquifer with a general-head inland boundary. Journal of Hydrology. 522, 135, 2015.

6. MOLERIO L. LESLIE F. Vulnerability indicators of karstic aquifers. Ingeniería Hidráulica y Ambiental, 25 (3), 56, 2004 [In Spanich].

7. LUOMA S., OKKONEN J., KORKKA N. K. Comparison of the AVI, modified SINTACS and GALDIT vulnerability methods under future climate-change scenarios for a shallow low-lying coastal aquifer in southern Finland. Hydrogeology Journal, 1, 2016.

8. BENAVENTE J., F. CARRASCO C., ALMÉCIJA P. RODRÍGUEZ Y., CRUZ S. The transition zone of freshwater-brine under the edge of the salt lagoon of 
Fuente de Piedra (Málaga). Geogaceta. 14, 6, 1993 [In Spanish].

9. GRANIEL E., VERA V. I., GONZÁLEZ L. Dynamics of the salt interface and water quality on the northeastern coast of Yucatan. Ingeniería, 8, (3), 15, 2004 [In Spanish].

10. RAVIKUMAR P., SOMASHEKAR R.K., PRAKASH K.L. A comparative study on usage of Durov and Piper diagrams to interpret hydrochemical processes in groundwater from SRLIS river basin, Karnataka, India. 80, 31073, 2015.

11. MU X., BROWER J., SIEGEL D.I., FIORENTINO II A.J., AN S., CAI Y., XU D., JIANG H. Using integrated multivariate statistics to assess the hydrochemistry of surface water quality, Lake Taihu basin, China. Journal of Limnology, 74 (2), 234, 2015.

12. BIGLARI H., CHAVOSHANI A., JAVAN N., HOSSEIN M. A. Geochemical study of groundwater conditions with special emphasis on fluoride concentration, Iran. Desalination and Water Treatment, 57, 1, 2016.

13. PIPER A. A graphic procedure in the geochemical interpretation of water-analyses. Trans am geophysics union 25, 914, 1944.

14. PEETERS L. A background color scheme for piper plots to spatially visualize hydrochemical patterns. Groundwater, 52 (1), 2, 2014

15. LI Y., TANG Y., ZHAO N., JIN B. Analysis on Chemical Characteristics and Prospect of Development and Utilization of Geothermal Fluids in Tuanbo New Town, Tianjin. Analysis, 19, 25, 2015.

16. KUMAR P.S. Interpretation of groundwater chemistry using piper and Chadha's diagrams: a comparative study from Perambalur Taluk. Elixir Geosci, 54, 12208, 2013.

17. SUMA C.S., SRINIVASAMOORTHY K., SARAVANAN K., FAIZALKHAN A., PRAKASH R., GOPINATH S. Geochemical modeling of groundwater in Chinnar River basin: a source identification perspective. Aquatic Procedia, 4, 986, 2015.

18. CHADHA D.K. A proposed new diagram for geochemical classification of natural waters and interpretation of chemical data. Hydrogeology Journal, 7 (5), 431, 1999.

19. TEIXIDÓ T. The surface geophysical methods: a useful tool for the engineer. Procedia Engineering, 46, 89, 2012.

20. PAZZI V., TAPETE D., CAPPUCCINI L., FANTI R. An electric and electromagnetic geophysical approach for subsurface investigation of anthropogenic mounds in an urban environment. Geomorphology, 273, 335, 2016.

21. YANG X., LASSEN R. N., JENSEN K. H., LOOMS M. C. Monitoring $\mathrm{CO}_{2}$ migration in a shallow sand aquifer using $3 \mathrm{D}$ crosshole electrical resistivity tomography. International Journal of Greenhouse Gas Control, 42, 534, 2015.

22. SCHMIDT H.C., BERGMANN P., BÖSING D., LABITZKE T., MÖLLER M., SCHRÖDER S., WAGNER F., SCHÜTT $\mathrm{H}$. Electrical resistivity tomography (ERT) for monitoring of $\mathrm{CO}_{2}$ migration-from tool development to reservoir surveillance at the Ketzin pilot site. Energy Procedia, 37, $4268,2013$.

23. SCHMIDT H.C., BERGMANN P., LABITZKE T., WAGNER $\mathrm{F} . \mathrm{CO}_{2}$ migration monitoring by means of electrical resistivity tomography (ERT) - review on five years of operation of a permanent ERT system at the ketzin pilot site. Energy Procedia 63, 4366, 2014.

24. CHAMBERS J.E., MELDRUM P.I., WILKINSON P.B., WARD W., JACKSON C., MATTHEWS B., JOELC P., KURASA O., BAIB L., UHLEMANNA S., GUNN D. Spatial monitoring of groundwater drawdown and rebound associated with quarry dewatering using automated time- lapse electrical resistivity tomography and distribution guided clustering. Engineering Geology, 193, 412, 2015.

25. WAGNER F.M., MÖLLER M., SCHMIDT H.C., KEMPKA T., MAURER H. Monitoring freshwater salinization in analog transport models by time-lapse electrical resistivity tomography. Journal of Applied Geophysics, 89, 84, 2013.

26. ABBAS A.M., GHAZALA H.H., MESBAH H.S., ATYA M.A., RADWAN A., HAMED D.E. Implementation of ground penetrating radar and electrical resistivity tomography for inspecting the Greco-Roman Necropolis at Kilo 6 of the Golden Mummies Valley, Bahariya Oasis, Egypt. NRIAG Journal of Astronomy and Geophysics, 5, 147, 2016.

27. CHAMBERS J.E., MELDRUM P.I., WILKINSON P.B., WARD W., JACKSON C., MATTHEWS B., JOEL P., KURAS O., BAI L., UHLEMANN S., GUNN D. Spatial monitoring of groundwater drawdown and rebound associated with quarry dewatering using automated timelapse electrical resistivity tomography and distribution guided clustering. Engineering Geology, 193, 412, 2015.

28. GINGINE V., DIAS A.S., CARDOSO R. Compaction Control of Clayey Soils Using Electrical Resistivity Charts. Procedia Engineering, 143, 803, 2016.

29. ARCHIE G.E. The electrical resistivity $\log$ as an aid in determining some reservoir characteristics. Trans. AIMME 146, 54, 1942.

30. SOUPIOS P.M., KOULI M., VALLIANATOS F., VAFIDIS A., STAVROULAKIS G. Estimation of aquifer hydraulic parameters from surficial geophysical methods: A case study of Keritis Basin in Chania (Crete-Greece). Journal of Hydrology, 338 (1), 122, 2007.

31. KOSINSKI W.K., KELLY W.E. Geoelectric soundings for predicting aquifer properties. Ground Water, 19 (2), 163, 1981.

32. PONZINI G., OSTROMAN A., MOLINARI M. Empirical relation between electrical transverse resistance and hydraulic transmissivity. Geoexploration, 22, 1, 1984.

33. NIWAS S., CELIK M. Equation estimation of porosity and hydraulic conductivity of Ruhrtal aquifer in Germany using near surface geophysics. Journal of Applied Geophysics, 84, 77, 2012.

34. EBONG E.D., AKPAN A.E., ONWUEGBUCHE A.A. Estimation of geohydraulic parameters from fractured shales and sandstone aquifers of Abi (Nigeria) using electrical resistivity and hydrogeologic measurements. Journal of African Earth Sciences, 96, 99, 2014.

35. GEORGE N.J., IBUOT J.C., OBIORA D.N. Geoelectrohydraulic parameters of shallow sandy aquifer in Itu, Akwa Ibom State (Nigeria) using geoelectric and hydrogeological measurements. Journal of African Earth Sciences, 110, 52, 2015.

36. INEGI. Municipal statistical notebook, Guasave, Sinaloa. Aguascalientes, Mexico, 1, 192, 2000 [In Spanish].

37. CONAGUA (National Water Commission), Technical file justifying the aquifer of the Sinaloa River for the publication of availability in the Official Gazette of the Federation. Culiacán, Sinaloa. 2002 [In Spanish].

38. KELLER G.V., FRISCHKNECHT F.C. Electrical methods in geophysical prospecting. Pergamon Press Inc., Oxford. 1966.

39. GEONICS LIMITED 2010. Geophysical Instrumentation for exploration and the environment .http://www.geonics. $\mathrm{com} / \mathrm{html} /$ products.html

40. LOKE M.H., BARKER R.D. Practical techniques for 3D resistivity surveys and data inversion. Geophysical Prospecting, 44, 499, 1996.

41. LOKE M.H., BARKER R.D. Rapid least-squares inversion 
of apparent resistivity pseudosections using a quasi-Newton method. Geophysical Prospecting, 44, 131, 1996.

42. LOKE M.H., CHAMBERS J.E., RUCKER D.F., KURAS O., WILKINSON P.B. Recent developments in the directcurrent geoelectrical imaging method. Journal of Applied Geophysics, 95, 135, 2013.

43. RICHARDS L.A. Diagnosis and rehabilitation of saline and sodium soils. Manual 60. Staff of the USA Salinity Laboratory. Department of Agriculture of the United States of America., ed. LIMUSA, 172, 1954 [In Spanish].

44. HEATH R.C. Basic Ground-Water Hydrology. U.S. Geological Survey Water-Supply paper 2220. United States Geological Survey, 81, 1991.

45. HERBER L.G. Electrical conductivity apparent as a tool to define specific site Management Zones in corn (Zea mays) in the Province of Corrientes (Doctoral dissertation, Facultad de Ciencias Agrarias y Forestales). 2011.

46. SOLA F., ESPAÑA S., VALLEJOS Á., PULIDO B.A. Hydrogeochemical characterization of the groundwater of Cabo de Gata (Almería). GEOGACETA, 58, 135, 2015 [In Spanish].

47. ALY A.A., KISHK F.M., GABER, H.M., AL-OMRAN A.M. Long-term detection and hydrochemistry of groundwater resources in Egypt: Case study of Siwa Oasis. Journal of the Saudi Society of Agricultural Sciences, 15 (1), 67, 2014.

48. GIBBS R. Mechanisms Controlling World Water Chemistry. Science, 170, 1088, 1970.

49. DAMIANO F., MAGLIANO M.A., CASTILLO R.F. Estimation of the chemical composition of groundwater from its salinity. In National Water Congress. 25. Conagua 2015. 06, 15, 2015

50. NARVÁEZ H., BUSTAMANTE B.I., COMBATT E. Estimation of salinity in soils of river delta of Sinu in Colombia, through of linear multiple regression models. Idesia (Arica), 32 (3), 81, 2014 [In Spanish]. 